\title{
Distribution of mercury species in different tissues and trophic levels of commonly consumed fish species from the south Bay of Biscay (France)
}

\author{
Mille Tiphaine ${ }^{1}$, Bisch Amaëlle ${ }^{1}$, Caill-Milly Nathalie ${ }^{2}$, Cresson Pierre ${ }^{3}$, Deborde Jonathan ${ }^{4}$, \\ Gueux Aurore ${ }^{4}$, Morandeau Gilles ${ }^{2}$, Monperrus Mathilde ${ }^{1,{ }^{*}}$
}

\author{
1 Université de Pau et des Pays de l'Adour, E2S UPPA, CNRS, IPREM-MIRA, UMR 5254, 64600 \\ Anglet, France \\ 2 Ifremer, LITTORAL, Laboratoire Environnement Ressources d'Arcachon, 64600 Anglet, France \\ 3 Ifremer, Centre Manche Mer du Nord, Laboratoire Ressources Halieutiques Manche Mer du Nord, 150 \\ quai Gambetta, 62200 Boulogne sur Mer, France \\ 4 Ifremer, LITTORAL, Laboratoire Environnement et Ressources des Pertuis Charentais (LER/PC), \\ BP133, 17390 La Tremblade, France \\ * Corresponding author : Mathilde Monperrus, email address : mathilde.monperrus@univ-pau.fr
}

\begin{abstract}
:
Mercury $(\mathrm{Hg})$ is a contaminant of global concern in marine ecosystems, notably due to its ability to accumulate and concentrate in food webs. Concentrations of total mercury (THg), methylmercury (MeHg) and inorganic mercury $(\mathrm{IHg})$ were assessed and compared in different tissues (liver, muscle, and gonads) of three common fish species (hake Merluccius merluccius, red mullet Mullus surmuletus, and sole Solea solea) from the continental shelf from the southern part of the Bay of Biscay. Several studies investigated $\mathrm{Hg}$ concentration in fish muscle, but few assessed concentrations in other organs, despite the importance of such data to understand contaminant organotropism and metabolization. Results showed that trophic position and feeding habitat are required to understand the variability of $\mathrm{Hg}$ concentration in muscle between fish species. In addition, high $\mathrm{MeHg} / \mathrm{THg}$ ratio in muscle could be explained by the predatory behavior of the studied fish species and the biomagnification of this $\mathrm{Hg}$ species within the food web, $\mathrm{MeHg}$. Despite differences between species, $\mathrm{Hg}$ concentration was always higher in muscle (from $118 \pm 64$ to $338 \pm 101 \mathrm{ng} \mathrm{g}-1$ w.w.) and liver (from $122 \pm 108$ to $271 \pm 95 \mathrm{ng}$ g-1 w.w.). These results can be related to physiological processes especially the MeHg detoxification strategies.
\end{abstract}

\section{Highlights}

High $\mathrm{MeHg} / \mathrm{THg}$ ratio in fish muscle explained by $\mathrm{MeHg}$ biomagnification. Trophic position and feeding habitat cause $\mathrm{Hg}$ variation in fish muscle. Hg concentration was higher in muscle and liver for all fish species. Difference in $\mathrm{Hg}$ distribution could be related to differential $\mathrm{MeHg}$ detoxification strategies. 
Keywords : Methylmercury, Contamination, Organotropism, Bioaccumulation, Teleostei 


\section{Introduction}

Contaminants in marine environments are of high concern for both ecological and human health reasons.

Within the Marine Strategy Framework Directive (MSFD), the European Union fosters the achievement of good environmental status of marine waters by 2020. Two MSFD descriptors deal with contaminants: descriptor 8 aims at limiting contaminant levels below adverse effect for ecosystem functioning while descriptor 9 aims at limiting contaminant levels below sanitary threshold, i.e. below adverse levels for human consumers (EC, 2008). Among the contaminants of interest, mercury $(\mathrm{Hg})$ is a non-essential heavy metal, recognized as hazardous for living organisms. Hg is emitted in the environment from natural (e.g. volcanic eruptions) and anthropogenic sources (e.g. burning of fossil fuels or industry) in a gaseous form. It became widespread in the aquatic ecosystems mainly through atmosphere due to its high volatility. After deposition as inorganic species ( $\mathrm{IHg}$ ), it can be converted into its organic methylated form - namely methylmercury (MeHg)- by bacterial activities (Villar et al., 2020). All Hg species (organic and inorganic) are bioaccumulated in organisms but only MeHg is well-known for its biomagnification property, namely the trend for increasing concentrations along food webs (Baeyens et al., 2003; Bryan et al., 1979). Because feeding is the main pathway responsible for $\mathrm{Hg}$ transfer in marine organisms (Cresson et al., 2014; Hall et al., 1997), high $\mathrm{Hg}$ concentrations are generally observed in high trophic level species such as piscivorous fish species (Cossa et al., 2012), mammals (Brown et al., 2018; Pinzone et al., 2019) or sharks (Endo et al., 2008; McKinney et al., 2016). In addition, MeHg dominates in fish muscle, which may imply a high toxicological hazard for humans, considering that most wild fish species consumed are at high trophic level (Lavoie et al., 2018; Pauly et al., 1998) and that muscle is the main edible fish tissue. Therefore, due to $\mathrm{Hg}$ potent high neurotoxic effects for human, Hg concentrations were largely monitored (1) in fish muscle, to document potential health hazard, and (2) in aquatic biota, as to reconstruct Hg pathway along food chains (Lavoie et al., 2013). However, research on other tissues is important to understand $\mathrm{Hg}$ major contamination targets. Moreover, $\mathrm{Hg}$ species distribution allows to elucidate tissue-specific bioaccumulation pathways and to investigate different behavior for organic and inorganic $\mathrm{Hg}$ species, with implications for organisms toxicokinetics (Kasper et al., 2009). In addition to the organism metabolic activity, fish bioaccumulation pattern is a complex process, where $\mathrm{Hg}$ concentrations result from combined effect of both abiotic (e.g. habitats of 
species (Chouvelon et al., 2012; Cresson et al., 2015a)) and biotic factors (e.g. fish growth, trophic functioning of ecosystems (Chouvelon et al., 2018; Cossa et al., 2012; Cresson et al., 2014)). In this context, the aim of this study was to investigate $\mathrm{Hg}$ species (MeHg and $\mathrm{IHg}$ ) distribution among three organs (muscle, liver, and gonad) in three commercial fish species, considering that differences in diet and feeding habitat can be potential drivers of differences.

\section{Material and methods}

\section{Sampling area}

Fish were sampled in the southern part of the Bay of Biscay, in the Eastern Atlantic Ocean (Figure 1). This area is characterized by a rocky zone in the south, a canyon in the center and a sandy zone in the north. The Adour, the small Pyrenean and northern Spanish coastal rivers from the Cantabrian chain contribute to the volumes of suspended matter exported to the ocean; the Adour contributes $0.2510^{6}$ tons per year and the Pyrenean coastal rivers $1.910^{6}$ tons per year (Jouanneau et al., 1999; Maneux et al., 1999). The hydrodynamics of the Basque plateau is dominated by the processes associated with swells and storms (Uriarte et al., 2004). The southeastern part of the Bay of Biscay is characterized by the presence of a contour current that runs along the edge of the Basque-Cantabrian platform (from west to east), then the edge of the Aquitaine platform (from south to the North). This current results from a contrast of density between the waters of the platforms and the deep waters.

\section{Species selection and sampling collection}

Three fish species were selected for their commercial interest in the Bay of Biscay, their availability regarding sampling on various habitats characteristics and different feeding habitats. Hake (Merluccius merluccius) is a demersal species with high commercial interest (19\% of the landing value in 2017) within the Bay of Biscay (Ifremer Fisheries Information system, 2018). Canyons areas, especially the continental shelf accretion, promote concentrations of adults in the south Bay of Biscay (Alvarez et al., 2001; Sánchez and Gil, 2000; Woillez et al., 2007). Two common benthic fishes, common sole (Solea solea) and striped red mullet (Mullus surmuletus) representing $6 \%$ and $1 \%$ of the landing value respectively (Ifremer Fisheries Information system, 2018) were also selected. Sole habitat is fine and 
muddy sands or vases (Koutsikopoulos and Lacroix, 1992) whereas red mullet lives on sandy, gravelly, rocky, shellfish bottoms (Quéro and Vayne, 1986). A total of 90 individuals of the three species were caught by fishermen in 2017 and 2018: 32 hakes from the continental shelf of the Capbreton canyon, 17 red mullets from the rocky bottom of French Basque coast, and 41 soles caught on the sandy Landes coast (Table $1 \&$ Figure 1). In order to investigate sources of organic matter, the sampling also included zooplankton samples collected with a vertical plankton net (200 $\mu \mathrm{m}$ mesh size) at two stations in the Adour plume (Zooplankton P, 20m depth) and in the head of the Capbreton canyon (Zooplankton C, $120 \mathrm{~m}$ depth). Surface water samples $(-1 \mathrm{~m})$ were also collected at these two points and in the Adour estuary with a $20 \mathrm{~L}$ Niskin bottle, and directly filtered through pre-combusted $\left(4 \mathrm{~h}-450{ }^{\circ} \mathrm{C}\right) \mathrm{GF} / \mathrm{F}$ filters $(47 \mathrm{~mm} \emptyset)$ for $\mathrm{C}$ and $\mathrm{N}$ isotopic analyses of suspended particulate organic matter (POM). Prior to analyses, filters were dried overnight at $50{ }^{\circ} \mathrm{C}$ and were decarbonated by contact with $\mathrm{HCl}$ vapor $(8 \mathrm{~h})$, following a classical protocol (e.g. Dubois et al., 2012; Liénart et al., 2016; Savoye et al., 2012). In order to limit the effect of several biotic factors such as fish age and/or length (Cresson et al., 2015a), individuals were caught in a limited range of fish size, corresponding to the age of the first reproduction. Hake breeds around $40 \mathrm{~cm}$ for males (2 years old) and around 50-60 cm (3-4 years old) for females. For sole, the first sexual maturity usually occurs at the age of 2 or 3 years and around 25 to $30 \mathrm{~cm}$ long (Koutsikopoulos and Lacroix, 1992). In the Bay of Biscay, sizes of first sexual maturity for red mullet were around $16 \mathrm{~cm}$ and $18 \mathrm{~cm}$ for males and females, respectively (Dorel, 1986). The size and sex effects on $\mathrm{Hg}$ burden have been tested. 


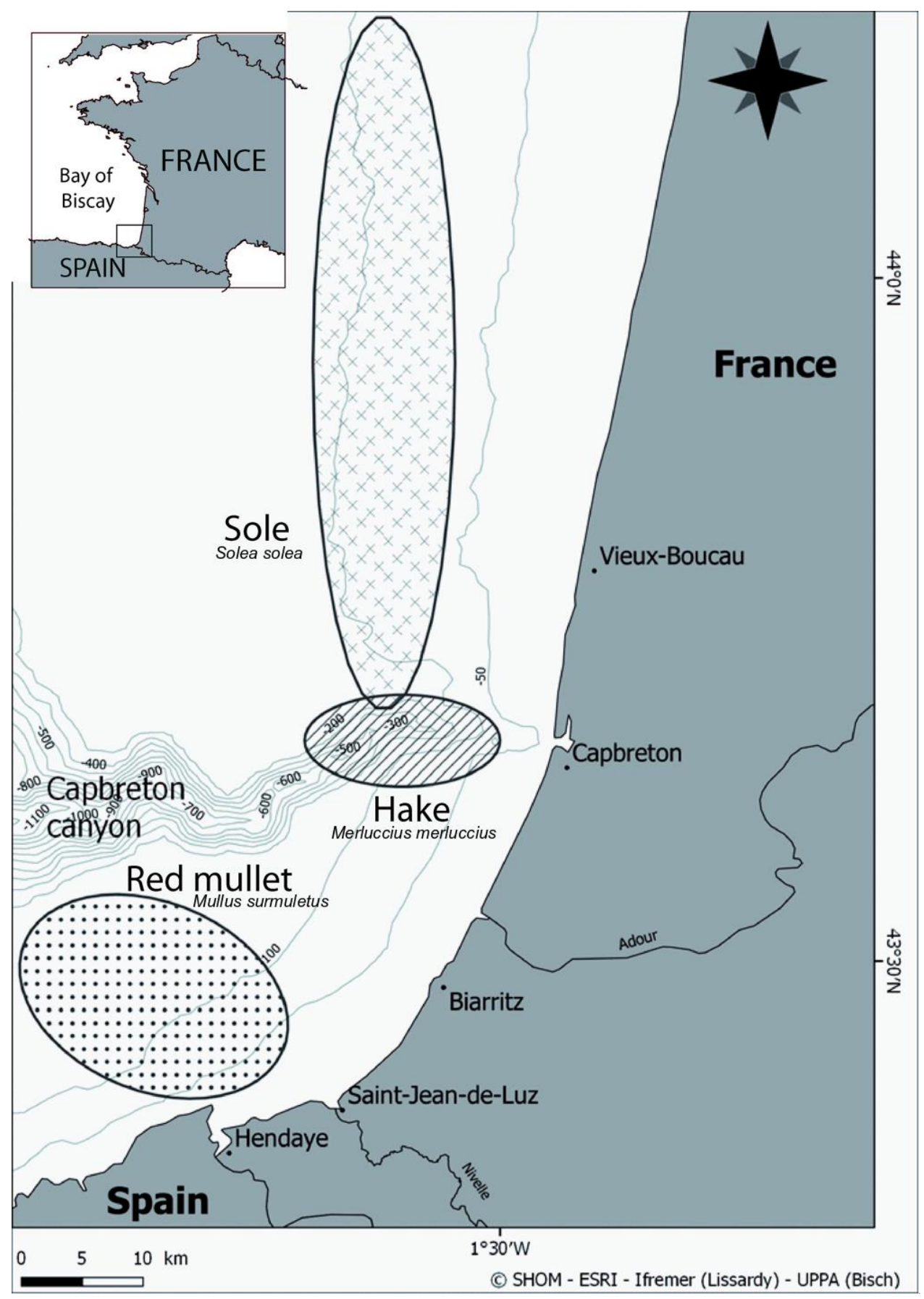

Figure 1: Map of sampling areas for the three fish species studied.

\section{Mercury species analysis}

For all individuals, after being weighted and measured, white muscle (without skin), liver and gonad were dissected out. $\mathrm{Hg}$ was measured in all tissues, while isotopic analyses were performed in muscle only, as this tissue is the most classical and the most suited to estimate fish average trophic position. All samples were then freeze-dried, homogenized and grinded. 
Hg species were measured by capillary gas chromatography (Focus GC, Thermo Electron) connected to an inductively coupled plasma mass spectrometer (ICPMS X2 series, Thermo Electron). Methodology and analytical set-up for the GC-ICP-MS for Hg speciation analysis are detailed in Monperrus et al. (2005). Briefly, about $100 \mathrm{mg}$ of homogenized dry tissue were digested with $5 \mathrm{ml}$ TMAH (Tetramethylammonium hydroxide) under a microwave field and then centrifuged to remove solid particles. The supernatant, stored at $4^{\circ} \mathrm{C}$, was then submitted to derivatization using sodium tetraethylborate (3\%). Quantification of $\mathrm{Hg}$ species was performed by species specific isotope dilution, by adding the appropriate amount of isotopically enriched $\mathrm{Hg}$ standards $\left({ }^{199} \mathrm{IHg}\right.$ and ${ }^{201} \mathrm{MeHg}$ ), and by applying isotope pattern deconvolution for data processing (Rodríguez Martín-Doimeadios et al., 2004). $\mathrm{THg}$ concentrations are equal to the sum of $\mathrm{IHg}$ and $\mathrm{MeHg}$ concentrations. $\% \mathrm{MeHg}$ was calculated as the ratio between MeHg and THg. Analytical performances were checked by blanks and by Certified reference materials (CRMs) DOLT-4 (Dogfish liver) and TORT-2 (Lobster hepatopancreas) from the National Research Council of Canada (CNRC) and BCR464 (Tuna fish muscle) from the Institute for Reference Materials and Measurements (IRMM). Limits of quantification were $1.2 \mathrm{ng} \mathrm{g}^{-1}$ for $\mathrm{Hg}$ species. $\mathrm{Hg}$ species concentrations were expressed relatively to dry weight. The conversion of $\mathrm{Hg}$ concentrations in wet weight (w.w.) was achieved with a conversion factor obtained by weighing the mass difference before and after freeze-drying for all tissues.

\section{Carbon and nitrogen stable isotope analysis}

Muscle stable isotopic ratios were measured with a Thermo Scientific ${ }^{\circledR}$ Delta V Advantage mass spectrometer coupled to a Thermo Scientific ${ }^{\circledR}$ Flash EA1112 elemental analyzer following routine protocol of the Plateforme Spectrometrie Ocean (https://www-iuem.univ-brest.fr/delta-v-plus-ea$\mathrm{gb} /$ ?lang=en) and used in previously published paper (e.g. Mille et al., 2020; Timmerman et al., 2020). For suspended POM samples, carbon and nitrogen isotopic compositions were analyzed using an isotope ratio mass spectrometer (IRMS; Isoprime, GV Instruments®) coupled with an elemental analyzer (ThermoFisher ${ }^{\circledR}$ Scientific Flash 2000). All isotopic results are presented in the classical $\delta$ notation, $\delta X=\left(\frac{R_{\text {sample }}}{R_{\text {standard }}}-1\right) \times 10^{3}$ where $\mathrm{X}$ is ${ }^{13} \mathrm{C}$ or ${ }^{15} \mathrm{~N}$ and $\mathrm{R}$ the ratio between heavy and light isotopes. Standard is Vienna Pee Dee Belemnite for $\delta^{13} \mathrm{C}$ and atmospheric nitrogen for $\delta^{15} \mathrm{~N}$. Carbon and nitrogen 
concentration were measured with the elemental analyzer and used to calculate molar $\mathrm{C} / \mathrm{N}$ ratios, classical proxy of lipid content in fish tissue for isotopic analyses. High $\mathrm{C} / \mathrm{N}$ ratios are usually interpreted as high lipid content that bias isotopic measurement. All $\mathrm{C} / \mathrm{N}$ ratios of fish samples were lower than 3.5 classically considered as the threshold values requiring lipid correction (Sweeting et al., 2006). Based on replicate measurements of internal laboratory standards, the analytical associated uncertainties were $0.13 \%$ and $0.12 \%$ for $\delta^{13} \mathrm{C}$ and $\delta^{15} \mathrm{~N}$ respectively, and $\leq 0.05$ for $\mathrm{C} / \mathrm{N}$ ratios.

\section{Statistical analysis}

For the three fish species, differences in $\mathrm{THg}$ concentration and proportion of $\mathrm{MeHg}(\% \mathrm{MeHg})$ among species were detected with Permutational multivariate analysis of variance (PERMANOVA). At the intra-specific level, the $\mathrm{Hg}$ species distribution between organs was investigated with PERMANOVA realized on $\mathrm{Hg}$ species concentrations. All statistical analyses were performed to the error threshold of 5\%, using the "vegan" (Oksanen et al., 2013) package in the statistical environment R Core Team (2018).

\section{Results}

\section{Feeding ecology}

Sole had the highest $\delta^{13} \mathrm{C}$ values $(-16.80 \pm 1.23 \%$ ), red mullet the lowest $(-18.72 \pm 0.64 \%$ ) and hake presented intermediate values $(-17.99 \pm 0.21 \%$ ) (Figure $2 \&$ Table 1$)$. Values for zooplankton were lower (Zooplankton G: $-20.56 \pm 0.90 \%$; Zooplankton P: $-20.28 \pm 1.18 \%$ ) followed by the POM values measured in surface waters (head of the canyon: $-22.59 \pm 0.78 \%$; Adour plume: $-22.87 \pm 0.92 \%$ and Adour estuary: $-27.84 \pm 0.93 \%$ ). Regarding $\delta^{15} \mathrm{~N}$, ratios were higher for hake $(13.64 \pm 0.34 \%$ ) than for the two other species $(12.50 \pm 0.31 \%$ and $12.10 \pm 0.58 \%$ for red mullet and sole respectively) and for zooplankton (Zooplankton C: $6.68 \pm 1.29 \%$; Zooplankton P: $6.44 \pm 1.23 \%$ ) and POM values (head of the canyon: $4.47 \pm 1.00 \%$; Adour plume: $4.56 \pm 0.78 \%$ and Adour estuary: $4.50 \pm 1.42 \%$ ). 


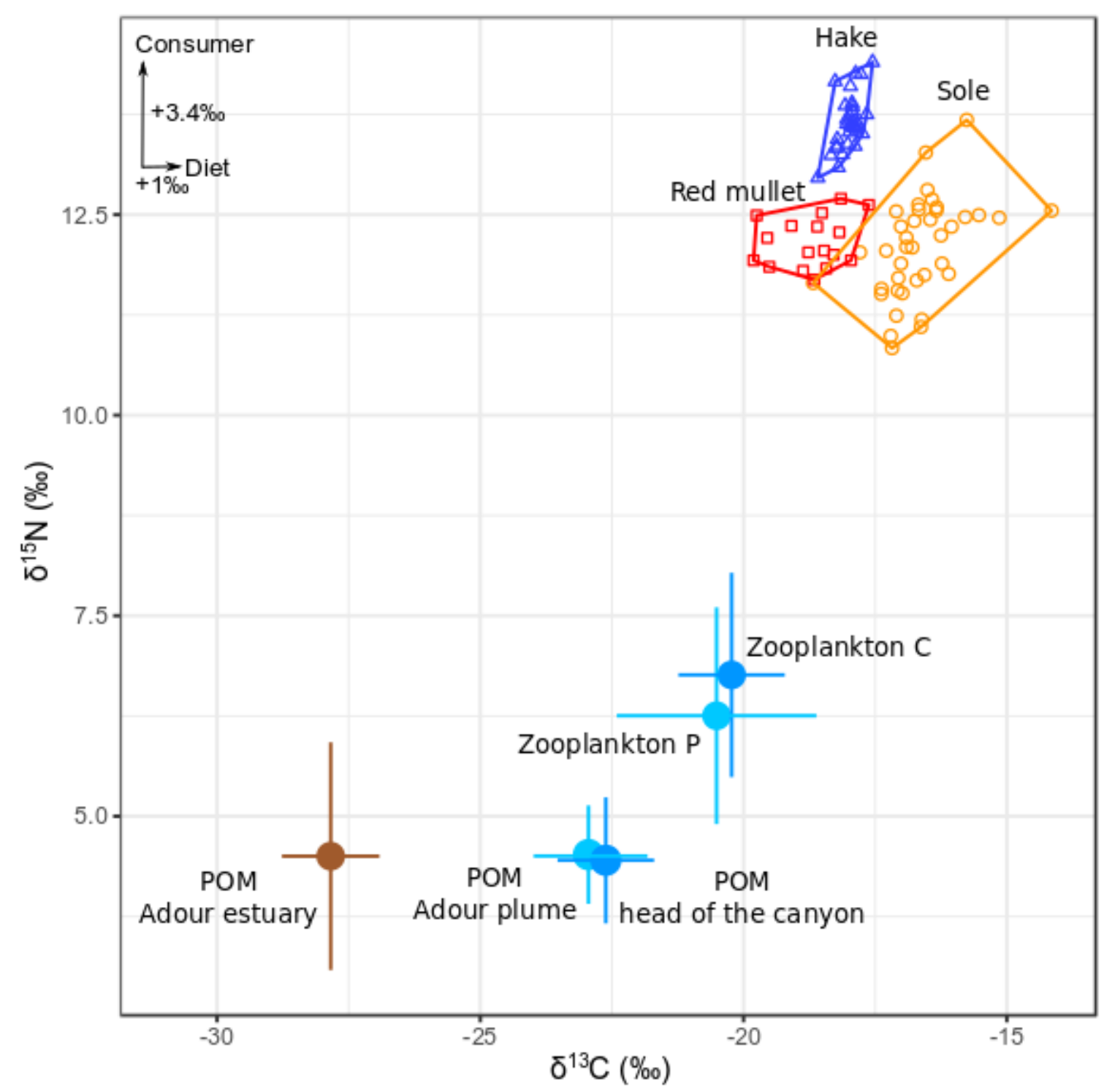

Figure 2: Relationships between carbon and nitrogen stable isotopes ratio measured in the three fish species (hake Merluccius merluccius, red mullet Mullus surmuletus and sole Solea solea). Signatures of particle organic matter of the Adour estuary, Adour plume, the head of the Capbreton canyon and signatures of zooplankton from Adour plume and the head of the Capbreton canyon are added (dot: mean, error bar: standard deviation). The theoretical isotopic change between a consumer and its diet $\left(+1 \%\right.$ for $\delta^{13} \mathrm{C},+3.4$ for $\left.\delta^{15} \mathrm{~N}\right)$ is represented in the upper left corner of the plot. 
Table 1: Biometric fish data: number of samples $\mathrm{N}$, fish total length and isotopic signatures (mean \pm standard deviation and range), and concentrations of total mercury (THg) and methylmercury (MeHg) according to organs/tissues (mean, standard deviation and range).

\begin{tabular}{|c|c|c|c|c|c|c|c|c|c|c|c|}
\hline \multirow{2}{*}{$\begin{array}{l}\text { Species } \\
\text { Diet and habitat }\end{array}$} & \multirow{2}{*}{$\mathrm{N}$} & \multirow{2}{*}{ Total length (mm) } & \multirow{2}{*}{$\delta^{13} \mathrm{C}(\%)$} & \multirow{2}{*}{$\delta^{15} \mathrm{~N}(\% 0)$} & \multirow{2}{*}{$\mathrm{C} / \mathrm{N}$} & \multicolumn{3}{|c|}{ THg (ng g ${ }^{-1}$ w.w.) } & \multicolumn{3}{|c|}{ MeHg (ng g ${ }^{-1}$ w.w.) } \\
\hline & & & & & & Muscle & Liver & Gonads & Muscle & Liver & Go \\
\hline $\begin{array}{l}\text { Hake } \\
\text { Merluccius merluccius } \\
\text { demersal piscivore } \\
\text { fish }\end{array}$ & 32 & $\begin{array}{l}550 \pm 60 \\
412-665\end{array}$ & $\begin{array}{c}-17.99 \pm 0.21 \\
-18.59--17.55\end{array}$ & $\begin{array}{l}13.64 \pm 0.34 \\
12.96-14.40\end{array}$ & $\begin{array}{l}3.15 \pm 0.03 \\
3.08-3.24\end{array}$ & $\begin{array}{c}268 \pm 155 \\
78-659\end{array}$ & $\begin{array}{l}123 \pm 43 \\
50-228\end{array}$ & $\begin{array}{l}57 \pm 27 \\
14-133\end{array}$ & $\begin{array}{l}177 \pm 89 \\
56-466\end{array}$ & $\begin{array}{c}73 \pm 37 \\
29-199\end{array}$ & $\begin{array}{l}41 \\
11\end{array}$ \\
\hline $\begin{array}{l}\text { Red mullet } \\
\text { Mullus surmuletus } \\
\text { benthic invertivore } \\
\text { rocky shore }\end{array}$ & 17 & $\begin{array}{l}241 \pm 14 \\
225-287\end{array}$ & $\begin{array}{c}-18.72 \pm 0.64 \\
-19.81--17.62\end{array}$ & $\begin{array}{l}12.15 \pm 0.31 \\
11.69-12.70\end{array}$ & $\begin{array}{l}3.19 \pm 0.02 \\
3.15-3.22\end{array}$ & $\begin{array}{l}338 \pm 101 \\
214-583\end{array}$ & $\begin{array}{l}271 \pm 95 \\
178-521\end{array}$ & $\begin{array}{l}87 \pm 23 \\
52-134\end{array}$ & $\begin{array}{l}235 \pm 57 \\
161-364\end{array}$ & $\begin{array}{l}225 \pm 84 \\
152-451\end{array}$ & $\begin{array}{l}67 \\
44\end{array}$ \\
\hline $\begin{array}{l}\text { Common sole } \\
\text { Solea solea } \\
\text { benthic invertivore } \\
\text { sandy-muddy shore }\end{array}$ & 41 & $\begin{array}{c}307 \pm 26 \\
254-360\end{array}$ & $\begin{array}{c}-16.80 \pm 1.23 \\
-22.99--14.15\end{array}$ & $\begin{array}{l}12.10 \pm 0.58 \\
10.84-13.27\end{array}$ & $\begin{array}{l}3.17 \pm 0.04 \\
3.11-3.32\end{array}$ & $\begin{array}{l}118 \pm 64 \\
38-340\end{array}$ & $\begin{array}{c}122 \pm 108 \\
44-543\end{array}$ & $\begin{array}{l}38 \pm 25 \\
10-141\end{array}$ & $\begin{array}{c}87 \pm 50 \\
27-260\end{array}$ & $\begin{array}{c}66 \pm 48 \\
21-244\end{array}$ & $\begin{array}{c}20 \\
5\end{array}$ \\
\hline
\end{tabular}


Interspecies difference in mercury species concentrations in muscle

In the present study, all individuals, except four hakes, had THg concentrations below the food safety thresholds determined by the European commission regulation [i.e. $0.5 \mu \mathrm{g} \mathrm{g}^{-1}$ w.w. for hake and sole, 1 $\mu \mathrm{g} . \mathrm{g}^{-1}$ W.w. for red mullet (EC, 2006)]. Values above the threshold measured for hakes ranged between 0.55 and $0.66 \mu \mathrm{g} \mathrm{g}^{-1} \mathrm{w} . \mathrm{w}$.

$\mathrm{Hg}$ concentrations in muscle were significantly lower $(\mathrm{F}=30.04$, p.value $<0.001)$ in sole $(118 \pm 64 \mathrm{ng}$ $\left.\mathrm{g}^{-1}\right)$ than in hake $\left(268 \pm 155 \mathrm{ng} \mathrm{g}^{-1}\right)$ and red mullet $\left(338 \pm 101 \mathrm{ng} \mathrm{g}^{-1}\right)$ (Table 1), but \% MeHg was comparable between these three species $(\sim 70 \%$ on average; $F=2.79$, p.value $>0.05$; Figure 3$)$.

Despite the sampling strategy to limit effect of biotic factors, a significant positive linear relationship between fish total length and $\mathrm{MeHg}$ in muscle was detected for hake only and a sex effect on $\mathrm{Hg}$ concentration was detected for sole only. Detailed results are presented in Table S1 and Figures S1 and S2. . 


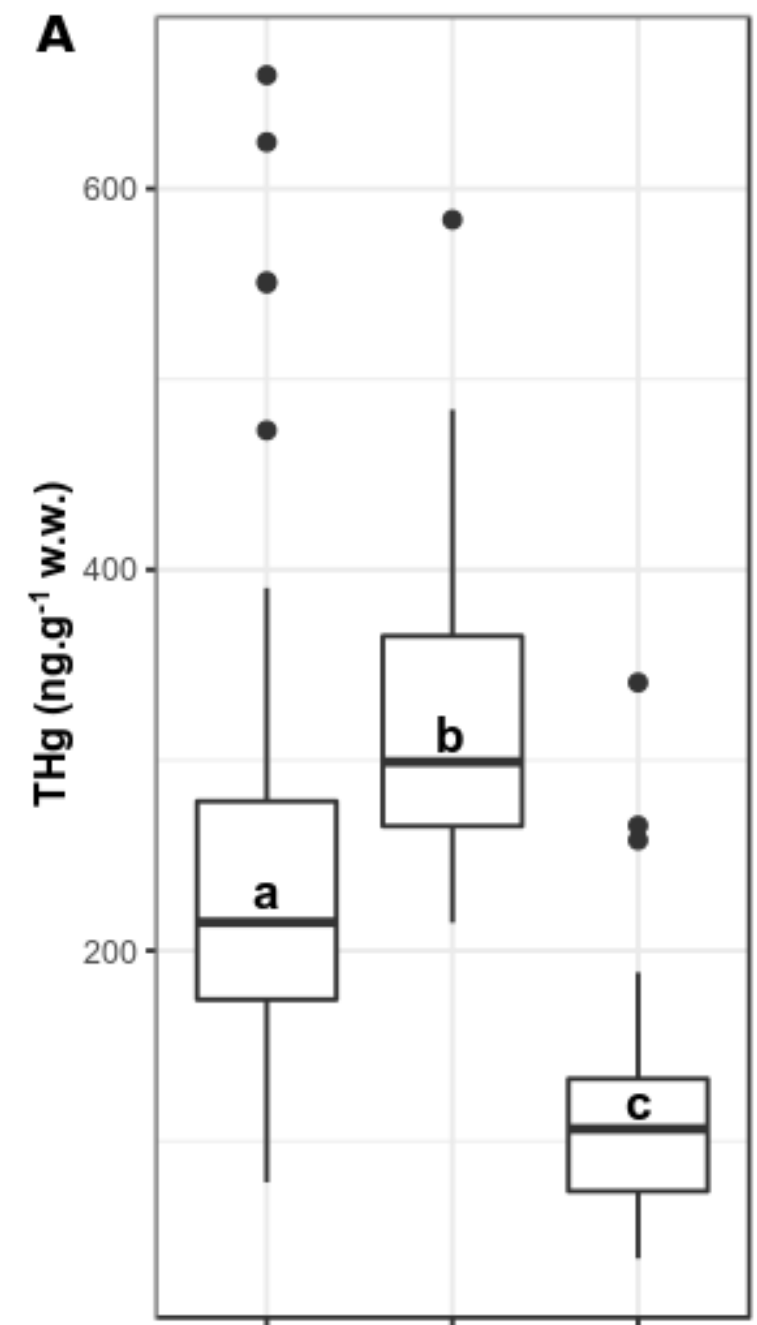

Hake Red mullet Sole

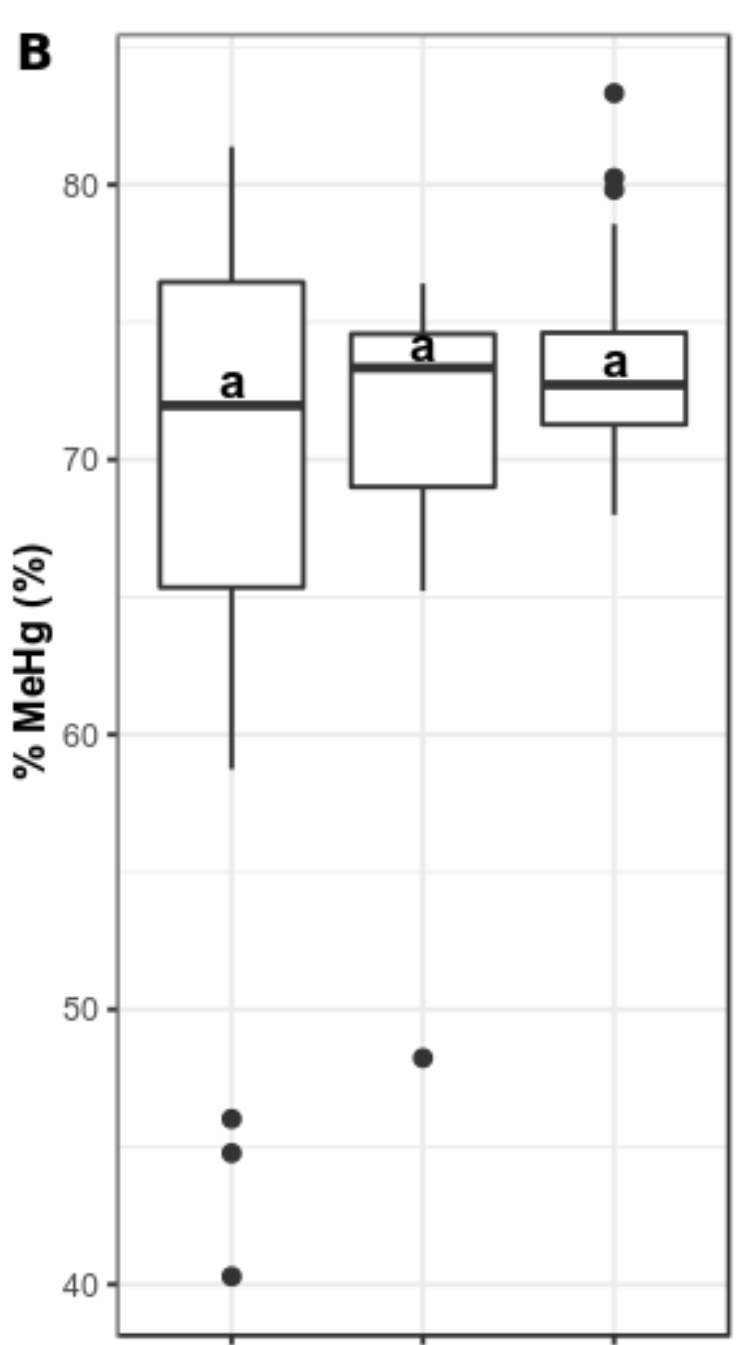

Hake Red mullet Sole

Figure 3: Total mercury concentration (A) and proportion of methylmercury (B) measured in muscle for the three species (hake Merluccius merluccius, red mullet Mullus surmuletus and sole Solea solea). The bottom and top of the box are the first and the third quartiles of the data distribution, the horizontal segment is the median, the whiskers represent the most extreme data point within 1.5 interquartile range and black points are data points out of this range. Letters highlight significant differences between species based on PERMANOVA.

\section{Distribution of mercury species between organs}

Among the three organs considered, muscle exhibited higher THg concentration than liver and gonads for hake and red mullet (Figure $4 \&$ Table 2). Concentration was not different between muscle and liver for sole, but higher than in the gonads (Figure 4). MeHg concentrations were higher in the muscle than in the liver and the gonads for the three species. Concentrations were always significantly lower in the gonads for the three species and higher in the muscle than in the liver, but this difference is significant for hake only. The pattern was somehow similar for IHg.

$\% \mathrm{MeHg}$ ratio was organ- and species-specific (Figure 4). In hake, ratios were significantly higher in gonad (average 74\%) than in muscle (average 66\%) than in liver (average 59\%). For red mullet, the 
highest \% MeHg was measured in liver (average 83\%) and in gonad (average 78\%), while sole had highest \% MeHg in muscle (average 74\%). 
Table 2: Differences in Hg species concentrations according to organs/tissues for the three fish species. Results were obtained with PERMANOVA illustrated by the F statistic together with the corresponding p.value.

\begin{tabular}{|l|c|c|c|}
\hline Species & \multicolumn{1}{|c|}{ THg } & MHg & IHg \\
\hline Make & $\mathrm{F}=40.15$, p.value $<0.001$ & $\mathrm{~F}=48.38, \mathrm{p}$. value $<0.001$ & $\mathrm{~F}=16.13$, p.value $<0.001$ \\
Merluccius merluccius & Muscle $>$ Liver $>$ Gonad & Muscle $>$ Liver $>$ Gonad & Muscle $>$ Liver $>$ Gonad \\
\hline Red mullet & $\mathrm{F}=43.48$, p.value $<0.001$ & $\mathrm{~F}=42.28$, p.value $<0.001$ & $\mathrm{~F}=25.17$, p.value $<0.001$ \\
Mullus surmuletus & Muscle $>$ Liver $>$ Gonad & Muscle $=$ Liver $>$ Gonad & Muscle $>$ Liver $>$ Gonad \\
\hline $\begin{array}{l}\text { Common sole } \\
\text { Solea solea }\end{array}$ & $\mathrm{F}=16.08$, p.value $<0.001$ & $\mathrm{~F}=27.23$, p.value $<0.001$ & $\mathrm{~F}=10.77$, p.value $<0.001$ \\
Muscle $=$ Liver $>$ Gonad & Muscle $=$ Liver $>$ Gonad & Muscle $=$ Liver $>$ Gonad \\
\hline
\end{tabular}



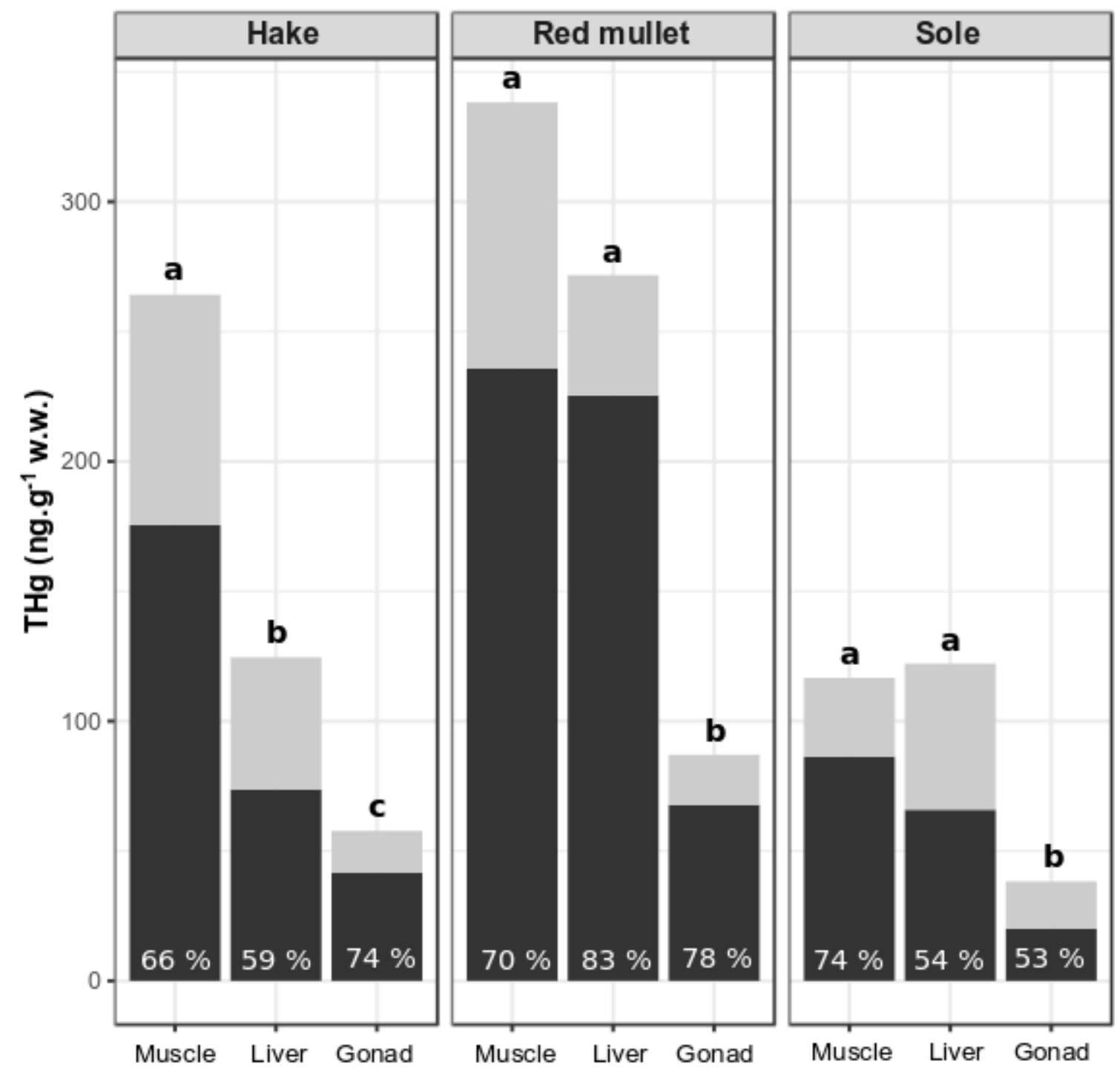

Figure 4: Distribution of $\mathrm{Hg}$ species according to organs for the three fish species (hake Merluccius merluccius, red mullet Mullus surmuletus and sole Solea solea). $\mathrm{MeHg}$ is displayed in black together with its percent relative to $\mathrm{THg}$, and $\mathrm{IHg}$ is in grey. Standard deviation are not added for graphical purposes. Significant differences between organs are highlighted with different letters.

\section{Discussion}

\section{Influence of diet and feeding habitat on Hg species concentrations in muscle}

The present study confirmed that $\mathrm{MeHg}$ represent the majority of $\mathrm{Hg}$ in fish, consistently with most literature records (Chouvelon et al., 2018; Pethybridge et al., 2010; Polak-Juszczak, 2018). These values can be linked with diet and especially with the trophic level of studied species. The three species are demersal predators (hake) or benthic invertivore (red mullet and sole). Hake diet is mostly based on fish like blue whiting, horse mackerel or sardine. Older individuals can exhibit cannibalism and consume young conspecifics (Mahe et al., 2007; Pinnegar, 2014; Velasco and Olaso, 2000). Red mullet and sole 
are benthic omnivorous fish consuming small crustaceans, worms and mollusks including small bivalves (Caill-Milly et al., 2017; Le Loc'h et al., 2008). The pattern observed for nitrogen isotopic ratio, with higher values for hake, is thus consistent the expected relative trophic position of the three fish species. Therefore, the species-specific \% MeHg observed in this study can be explained by the species diet which, in thus, involves the species specific accumulation of MeHg in muscle. This study highlighted also the biomagnification of $\mathrm{MeHg}$ and thus the transfer of this $\mathrm{Hg}$ species in the trophic network, resulting in high $\mathrm{MeHg}$ concentration in a piscivorous fish species (Cossa et al., 2012). However, the trophic position (estimated by $\delta^{15} \mathrm{~N}$ values) is not sufficient to explain the high variability of $\mathrm{Hg}$ concentration. Fish position in the water column was also an important factor, since pelagic species presented significantly lower $\mathrm{THg}$ concentration in muscle than the benthic species (Chouvelon et al., 2012). This pattern is exemplified here, as red mullet had highest $\mathrm{THg}$ concentrations than hake, despite having lower $\delta^{15} \mathrm{~N}$ values, consistently with the expected diet of the species. This pattern is even more surprising as hake was caught near the Capbreton canyon, a presumed sink for organic matter, sediment and contaminants especially Hg (Azaroff et al., 2019; Gaudin et al., 2006). This pattern was also observed in the Mediterranean, where fish living in canyons were more contaminated than counterparts living away (Cresson et al., 2016; Koenig et al., 2013). Hake contamination burden can be explained by the fact that all individuals in this study came from the continental shore at the head of the Capbreton canyon that was less contaminated in Hg than offshore (Azaroff et al., 2019). Isotopic values measured for hake are consistent with values previously measured for this species in the Bay of Biscay (Chouvelon et al., 2012; Cossa et al., 2012; Le Loc'h et al., 2008) and with the expected pelagic behavior of this species. It may thus be assumed that they poorly use benthic organic matter from the canyons, but fed above on the pelagic pathway.

Despite having similar $\delta^{15} \mathrm{~N}$ values, red mullet presented significantly higher THg concentrations than sole. This difference may result from differences in living and feeding habitat. Sole samples were caught in Landes coast, on a sandy-muddy shore, whereas red mullet were caught on rocky shore of the Basque coast. Isotopic difference between the species may support this assumption. Less negative $\delta^{13} \mathrm{C}$ value is commonly interpreted as a higher dependency on benthic-derived organic matter (Carlier et al., 2007; Cresson et al., 2020; Duffill Telsnig et al., 2019; Kopp et al., 2015; Le Loc'h et al., 2008). Isotopic ratios 
measured for sole can thus track the dependency of this species on the organic matter from the soft bottom sediment, potentially processed by the microbial pathway. On the rocky shore substrate where mullets were caught, pelagic production can enter directly in the food web after falling, since bacterial processes can be of less importance. In addition, mullets were caught close to the mouth of the Nivelle and Bidasoa Rivers. Riverine organic matter classically exhibit very negative carbon isotopic ratios, close to $-30 \%$ (Savoye et al., 2012). Values measured for the Adour river in the present $(-27.84 \pm$ 0.93\%) or previous studies (Bardonnet and Riera, 2005; Liénart et al., 2016) fall within this order of magnitude. In addition, Adour and others Basque rivers are sources of $\mathrm{Hg}$ for coastal areas (Sharif et al., 2014) notably since the Adour estuarine area is an area of MeHg production during the dry period by remobilization and methylation of $\mathrm{IHg}$ in surface sediment accumulated during the seasonal river inputs (Stoichev et al., 2004). Both isotopic and $\mathrm{Hg}$ values may thus testify a higher importance of riverine inputs to red mullet than to sole. But in the absence of accurate $\delta^{15} \mathrm{~N}$ values for the actual dietary items of both species (i.e. omnivorous crustaceans for red mullet, and suspension feeding bivalves for sole), inferring trophic level of sole and mullet directly from their $\delta^{15} \mathrm{~N}$ values should be done cautiously. Species can differ in their actual trophic level while exhibiting similar $\delta^{15} \mathrm{~N}$ values (Harmelin-Vivien et al., 2009). In this case, difference in trophic level may originate difference in Hg concentrations. Overall, this study confirms the importance of food sources within the feeding habitat/ecosystem as a major driver of $\mathrm{Hg}$ bioaccumulation in marine species muscles (Chouvelon et al., 2018; Cresson et al., 2015b).

\section{Differential Hg species distribution within organs}

As expected, $\mathrm{Hg}$ concentrations were higher in muscle and liver. This organotropism of $\mathrm{Hg}$ is consistent with other studies about $\mathrm{Hg}$ distributions in organs (Kasper et al., 2009; Polak-Juszczak, 2018). Biochemical characteristics of fish tissues, fish metabolism and $\mathrm{Hg}$ chemical behavior are the main drivers of these patterns. High $\mathrm{Hg}$ concentrations in muscle is classical and is usually explained by the affinity of $\mathrm{Hg}$ for thiols groups in some amino acids and thus proteins. Moreover, muscle is known to have a low MeHg demethylation or elimination rate (Maulvault et al., 2016). Liver is well known for being involved in detoxication processes, explaining why metal concentrations are usually higher in this organ than in others, i.e. as in sole in the present study. In addition, hake presented a significant 
difference of $\mathrm{Hg}$ concentrations between muscle and liver. These results suggested different capacities or physiological ability of $\mathrm{Hg}$ detoxification by the three fish species. $\mathrm{MeHg}$ from the fish body can be directly eliminated or indirectly through the liver by a redistribution of $\mathrm{MeHg}$ to other organs such as muscle (Wang et al., 2013). Another detoxication pathway is based on the transformation of MeHg to an inert $\mathrm{Hg}$ form by conjugating $\mathrm{MeHg}$ to selenium or proteins (e.g. glutathione and metallothionein), resulting a less harmful chemical form (Penglase et al., 2014). The lowest \% MeHg in sole liver could trace an increase importance of this pathway. Several studies demonstrated that flatfish such as the fourspot megrim Lepidorhombus boscii developed increased detoxication abilities, as a response to their chronic exposure to contaminant from diet and sediment (García et al., 2000; Martínez-Gómez et al., 2006). Therefore, differences in $\mathrm{Hg}$ distribution between tissues can be attributed to species related to physiological processes especially the detoxification strategies involved in $\mathrm{Hg}$ elimination and/or biotransformation (Le Croizier et al., 2018).

The gonads are composed mainly by lipoglycophosphoprotein, because teleost oocytes are mainly composed by vitelline proteins. Therefore, the proportion of amino acids in fish egg protein is somehow lower than in muscle (Kasper et al., 2009). However, one interesting fact is that, despite low $\mathrm{THg}$ concentration in gonads, hake and red mullet present high \% $\mathrm{MeHg}(74 \%$ and $78 \%$, respectively) in this tissue. MeHg is the toxic $\mathrm{Hg}$ form which can causes disturbance in fish eggs and larval stages (Latif et al., 2001). This result highlights the potential risk linked to MeHg maternal offloading, that is, the process whereby females transfer a portion of their accumulated contaminants to their offspring during reproduction (Govoni et al., 2017; Lyons and Lowe, 2013; Stefansson et al., 2014). Spawning was thus interpreted as a depuration process in $\mathrm{Hg}$ for females, in some freshwater fish species (Donald and Sardella, 2010; Hammerschmidt et al., 1999; Johnston et al., 2001).

\section{Conclusions}

In summary, this study has investigated and compared $\mathrm{Hg}$ species concentrations in the muscle of three commercial fish species. All individuals except four hakes had THg concentrations in muscle above the food safety thresholds determined by the European Commission regulation. We conclude that the distribution of $\mathrm{Hg}$ species (organic and inorganic) is fish species specific. Therefore, differences in $\mathrm{MeHg}$ bioaccumulation according to fish species are consequences of their diet, their metabolism 
(especially MeHg demethylation of processes) and their feeding habitat. Results of the present study confirms the importance of considering the environment in which they reside to investigate $\mathrm{Hg}$ bioaccumulation in marine fish. A larger sample size involving larger individuals could be considered, to confirm the results presented above and thus strengthen the European monitoring program.

\section{Acknowledgements}

The research leading to these results has received funding from the ERDF (European Regional Development Fund) and AEAG (Agence de l'Eau Adour-Garonne) under the MICROPOLIT project. Authors are grateful to Maud Ezan who helped in samples preparation and to Muriel Lissardy who drawn the sampling map. Thanks are due to teams of the Plateforme de Spectrometrie Océan (Rudolph Corvaisier and Oanez Lebeau) and of the Plateforme ISOTOPIE of EPOC (Nicolas Savoye and Karine Charlier) who performed the isotopic analyses.

\section{References}

Alvarez, P., Motos, L., Uriarte, A., Egaña, J., 2001. Spatial and temporal distribution of European hake, Merluccius merluccius (L.), eggs and larvae in relation to hydrographical conditions in the Bay of Biscay. Fish. Res. 50, 111-128. https://doi.org/10.1016/S0165-7836(00)00245-9

Azaroff, A., Tessier, E., Deborde, J., Guyoneaud, R., Monperrus, M., 2019. Mercury and methylmercury concentrations, sources and distribution in submarine canyon sediments (Capbreton, SW France): Implications for the net methylmercury production. Sci. Total Environ. 673, 511-521. https://doi.org/10.1016/j.scitotenv.2019.04.111

Baeyens, W., Leermakers, M., Papina, T., Saprykin, A., Brion, N., Noyen, J., De Gieter, M., Elskens, M., Goeyens, L., 2003. Bioconcentration and Biomagnification of Mercury and Methylmercury in North Sea and Scheldt Estuary Fish. Arch. Environ. Contam. Toxicol. 45, 498-508. https://doi.org/10.1007/s00244-003-2136-4

Bardonnet, A., Riera, P., 2005. Feeding of glass eels (Anguilla anguilla) in the course of their estuarine migration: new insights from stable isotope analysis. Estuar. Coast. Shelf Sci. 63, 201-209. https://doi.org/10.1016/j.ecss.2004.11.009

Brown, T.M., Macdonald, R.W., Muir, D.C.G., Letcher, R.J., 2018. The distribution and trends of persistent organic pollutants and mercury in marine mammals from Canada's Eastern Arctic. Sci. Total Environ. 618, 500-517. https://doi.org/10.1016/j.scitotenv.2017.11.052

Bryan, G.W., Waldichuk, M., Pentreath, R.J., Darracott, A., 1979. Bioaccumulation of Marine Pollutants. Philos. Trans. R. Soc. Lond. B. Biol. Sci. 286, 483-505.

Caill-Milly, N., Lissardy, M., Leaute, J.-P., 2017. Improvement of the fishery knowledge of striped red mullet of the Bay of Biscay. Working Document for the Working Group on Widely Distributed Stocks (WGWIDE). 30 August - 5 September 2017, Copenhagen (Denmark). https://archimer.ifremer.fr/doc/00399/51057/

Carlier, A., Riera, P., Amouroux, J.-M., Bodiou, J.-Y., Grémare, A., 2007. Benthic trophic network in the Bay of Banyuls-sur-Mer (northwest Mediterranean, France): An assessment based on stable carbon and nitrogen isotopes analysis. Estuar. Coast. Shelf Sci. 72, 1-15. https://doi.org/10.1016/j.ecss.2006.10.001 
Chouvelon, T., Cresson, P., Bouchoucha, M., Brach-Papa, C., Bustamante, P., Crochet, S., MarcoMiralles, F., Thomas, B., Knoery, J., 2018. Oligotrophy as a major driver of mercury bioaccumulation in medium-to high-trophic level consumers: A marine ecosystem-comparative study. Environ. Pollut. 233, 844-854. https://doi.org/10.1016/j.envpol.2017.11.015

Chouvelon, T., Spitz, J., Caurant, F., Mèndez-Fernandez, P., Autier, J., Lassus-Débat, A., Chappuis, A., Bustamante, P., 2012. Enhanced bioaccumulation of mercury in deep-sea fauna from the Bay of Biscay (north-east Atlantic) in relation to trophic positions identified by analysis of carbon and nitrogen stable isotopes. Deep Sea Res. Part Oceanogr. Res. Pap. 65, 113-124. https://doi.org/10.1016/j.dsr.2012.02.010

Cossa, D., Harmelin-Vivien, M., Mellon-Duval, C., Loizeau, V., Averty, B., Crochet, S., Chou, L., Cadiou, J.-F., 2012. Influences of Bioavailability, Trophic Position, and Growth on Methylmercury in Hakes (Merluccius merluccius) from Northwestern Mediterranean and Northeastern Atlantic. Environ. Sci. Technol. 46, 4885-4893. https://doi.org/10.1021/es204269w

Cresson, P., Bouchoucha, M., Miralles, F., Elleboode, R., Mahé, K., Marusczak, N., Thebault, H., Cossa, D., 2015a. Are red mullet efficient as bio-indicators of mercury contamination? A case study from the French Mediterranean. Mar. Pollut. Bull. 91, 191-199. https://doi.org/10.1016/j.marpolbul.2014.12.005

Cresson, P., Bouchoucha, M., Morat, F., Miralles, F., Chavanon, F., Loizeau, V., Cossa, D., 2015b. A multitracer approach to assess the spatial contamination pattern of hake (Merluccius merluccius) in the French Mediterranean. Sci. Total Environ. 532, 184-194. https://doi.org/10.1016/j.scitotenv.2015.06.020

Cresson, P., Chouvelon, T., Bustamante, P., Bănaru, D., Baudrier, J., Le Loc'h, F., Mauffret, A., Mialet, B., Spitz, J., Wessel, N., Briand, M.J., Denamiel, M., Doray, M., Guillou, G., Jadaud, A., Lazard, C., Prieur, S., Rouquette, M., Saraux, C., Serre, S., Timmerman, C.-A., Verin, Y., Harmelin-Vivien, M., 2020. Primary production and depth drive different trophic structure and functioning of fish assemblages in French marine ecosystems. Prog. Oceanogr. 186, 102343. https://doi.org/10.1016/j.pocean.2020.102343

Cresson, P., Fabri, M.C., Bouchoucha, M., Brach Papa, C., Chavanon, F., Jadaud, A., Knoery, J., Miralles, F., Cossa, D., 2014. Mercury in organisms from the Northwestern Mediterranean slope: Importance of food sources. Sci. Total Environ. 497-498, 229-238. https://doi.org/10.1016/j.scitotenv.2014.07.069

Cresson, P., Fabri, M.C., Miralles, F.M., Dufour, J.-L., Elleboode, R., Sevin, K., Mahé, K., Bouchoucha, M., 2016. Variability of PCB burden in 5 fish and sharks species of the French Mediterranean continental slope. Environ. Pollut. 212, 374-381. https://doi.org/10.1016/j.envpol.2016.01.044

Donald, D.B., Sardella, G.D., 2010. Mercury and other metals in muscle and ovaries of goldeye (Hiodon alosoides). Environ. Toxicol. Chem. 29, 373-379. https://doi.org/10.1002/etc.39

Dorel, D., 1986. Poissons de l'Atlantique Nord-Est, relations taille-poids. https://archimer.ifremer.fr/doc/00000/1289/

Dubois, S., Savoye, N., Grémare, A., Plus, M., Charlier, K., Beltoise, A., Blanchet, H., 2012. Origin and composition of sediment organic matter in a coastal semi-enclosed ecosystem: An elemental and isotopic study at the ecosystem space scale. J. Mar. Syst. 94, 64-73. https://doi.org/10.1016/j.jmarsys.2011.10.009

Duffill Telsnig, J.I., Jennings, S., Mill, A.C., Walker, N.D., Parnell, A.C., Polunin, N.V.C., 2019. Estimating contributions of pelagic and benthic pathways to consumer production in coupled marine food webs. J. Anim. Ecol. 88, 405-415. https://doi.org/10.1111/1365-2656.12929

EC, 2008. DIRECTIVE 2008/56/EC OF THE EUROPEAN PARLIAMENT AND OF THE COUNCIL of 17 June 2008 establishing a framework for community action in the field of marine environmental policy (Marine Strategy Framework Directive). Official Journal of the European Union.

EC, 2006. COMMISSION REGULATION (EC) No 1881/2006 of 19 December 2006 setting maximum levels for certain contaminants in foodstuffs. Official Journal of the European Union.

Endo, T., Hisamichi, Y., Haraguchi, K., Kato, Y., Ohta, C., Koga, N., 2008. Hg, Zn and Cu levels in the muscle and liver of tiger sharks (Galeocerdo cuvier) from the coast of Ishigaki Island, Japan: 
Relationship between metal concentrations and body length. Mar. Pollut. Bull. 56, 1774-1780. https://doi.org/10.1016/j.marpolbul.2008.06.003

García, L.M., Porte, C., Albaigés, J., 2000. Organochlorinated Pollutants and Xenobiotic Metabolizing Enzymes in W. Mediterranean Mesopelagic Fish. Mar. Pollut. Bull. 40, 764-768. https://doi.org/10.1016/S0025-326X(00)00023-0

Gaudin, M., Mulder, T., Cirac, P., Berné, S., Imbert, P., 2006. Past and present sedimentary activity in the Capbreton Canyon, southern Bay of Biscay. Geo-Mar. Lett. 26, 331. https://doi.org/10.1007/s00367-006-0043-1

Govoni, J.J., Morris, J.A., Evans, D.W., 2017. Tracing Dietary Mercury Histochemically, with Autometallography, through the Liver to the Ovaries and Spawned Eggs of the Spot, a Temperate Coastal Marine Fish. J. Aquat. Anim. Health 29, 173-180. https://doi.org/10.1080/08997659.2017.1349009

Hall, B.D., Bodaly, R.A., Fudge, R.J.P., Rudd, J.W.M., Rosenberg, D.M., 1997. Food as the Dominant Pathway of Methylmercury Uptake by Fish. Water. Air. Soil Pollut. 100, 13-24. https://doi.org/10.1023/A:1018071406537

Hammerschmidt, C.R., Wiener, J.G., Frazier, B.E., Rada, R.G., 1999. Methylmercury Content of Eggs in Yellow Perch Related to Maternal Exposure in Four Wisconsin Lakes. Environ. Sci. Technol. 33, 999-1003. https://doi.org/10.1021/es980948h

Harmelin-Vivien, M., Cossa, D., Crochet, S., Bănaru, D., Letourneur, Y., Mellon-Duval, C., 2009. Difference of mercury bioaccumulation in red mullets from the north-western Mediterranean and Black seas. Mar. Pollut. Bull. 58, 679-685. https://doi.org/10.1016/j.marpolbul.2009.01.004

Ifremer Fisheries Information system, 2018. Activité des navires de pêche 2017 : façade Atlantique. https://archimer.ifremer.fr/doc/00490/60174/

Johnston, T.A., Bodaly, R.A., Latif, M.A., Fudge, R.J., Strange, N.E., 2001. Intra- and interpopulation variability in maternal transfer of mercury to eggs of walleye (Stizostedion vitreum). Aquat. Toxicol. Amst. Neth. 52, 73-85. https://doi.org/10.1016/s0166-445x(00)00129-6

Jouanneau, J.M., Weber, O., Cremer, M., Castaing, P., 1999. Fine-grained sediment budget on the continental margin of the Bay of Biscay. Deep Sea Res. Part II Top. Stud. Oceanogr. 46, 22052220. https://doi.org/10.1016/S0967-0645(99)00060-0

Kasper, D., Palermo, E.F.A., Dias, A.C.M.I., Ferreira, G.L., Leitão, R.P., Branco, C.W.C., Malm, O., 2009. Mercury distribution in different tissues and trophic levels of fish from a tropical reservoir, Brazil. Neotropical Ichthyol. 7, 751-758. https://doi.org/10.1590/S167962252009000400025

Koenig, S., Fernández, P., Company, J.B., Huertas, D., Solé, M., 2013. Are deep-sea organisms dwelling within a submarine canyon more at risk from anthropogenic contamination than those from the adjacent open slope? A case study of Blanes canyon (NW Mediterranean). Prog. Oceanogr., Integrated study of a deep submarine canyon and adjacent open slopes in the Western Mediterranean Sea: an essential habitat 118, 249-259. https://doi.org/10.1016/j.pocean.2013.07.016

Kopp, D., Lefebvre, S., Cachera, M., Villanueva, M.C., Ernande, B., 2015. Reorganization of a marine trophic network along an inshore-offshore gradient due to stronger pelagic-benthic coupling in coastal areas. Prog. Oceanogr. 130, 157-171. https://doi.org/10.1016/j.pocean.2014.11.001

Koutsikopoulos, C., Lacroix, N., 1992. Distribution and abundance of sole (Solea solea (L.)) eggs and larvae in the Bay of Biscay between 1986 and 1989. Neth. J. Sea Res. 29, 81-91. https://doi.org/10.1016/0077-7579(92)90009-4

Latif, M.A., Bodaly, R.A., Johnston, T.A., Fudge, R.J., 2001. Effects of environmental and maternally derived methylmercury on the embryonic and larval stages of walleye (Stizostedion vitreum). Environ. Pollut. Barking Essex 1987 111, 139-148.

Lavoie, R.A., Bouffard, A., Maranger, R., Amyot, M., 2018. Mercury transport and human exposure from global marine fisheries. Sci. Rep. 8, 1-9. https://doi.org/10.1038/s41598-018-24938-3

Lavoie, R.A., Jardine, T.D., Chumchal, M.M., Kidd, K.A., Campbell, L.M., 2013. Biomagnification of Mercury in Aquatic Food Webs: A Worldwide Meta-Analysis. Environ. Sci. Technol. 47, 13385-13394. https://doi.org/10.1021/es403103t 
Le Croizier, G., Lacroix, C., Artigaud, S., Le Floch, S., Raffray, J., Penicaud, V., Coquillé, V., Autier, J., Rouget, M.-L., Le Bayon, N., Laë, R., Tito De Morais, L., 2018. Significance of metallothioneins in differential cadmium accumulation kinetics between two marine fish species. Environ. Pollut. 236, 462-476. https://doi.org/10.1016/j.envpol.2018.01.002

Le Loc'h, F., Hily, C., Grall, J., 2008. Benthic community and food web structure on the continental shelf of the Bay of Biscay (North Eastern Atlantic) revealed by stable isotopes analysis. J. Mar. Syst., Oceanography of the Bay of Biscay 72, 17-34. https://doi.org/10.1016/j.jmarsys.2007.05.011

Liénart, C., Susperregui, N., Rouaud, V., Cavalheiro, J., David, V., Del Amo, Y., Duran, R., Lauga, B., Monperrus, M., Pigot, T., Bichon, S., Charlier, K., Savoye, N., 2016. Dynamics of particulate organic matter in a coastal system characterized by the occurrence of marine mucilage - A stable isotope study. J. Sea Res. 116, 12-22. https://doi.org/10.1016/j.seares.2016.08.001

Lyons, K., Lowe, C.G., 2013. Mechanisms of maternal transfer of organochlorine contaminants and mercury in the common thresher shark (Alopias vulpinus). Can. J. Fish. Aquat. Sci. 70, 16671672. https://doi.org/10.1139/cjfas-2013-0222

Mahe, K., Amara, R., Bryckaert, T., Kacher, M., Brylinski, J.M., 2007. Ontogenetic and spatial variation in the diet of hake (Merluccius merluccius) in the Bay of Biscay and the Celtic Sea. ICES J. Mar. Sci. 64, 1210-1219. https://doi.org/10.1093/icesjms/fsm100

Maneux, E., Dumas, J., Clément, O., Etcheber, H., Charritton, X., Etchart, J., Veyssy, E., Rimmelin, P., 1999. Assessment of suspended matter input into the oceans by small mountainous coastal rivers: the case of the Bay of Biscay. Comptes Rendus Académie Sci. - Ser. IIA - Earth Planet. Sci. 329, 413-420. https://doi.org/10.1016/S1251-8050(00)80065-8

Martínez-Gómez, C., Campillo, J.A., Benedicto, J., Fernández, B., Valdés, J., García, I., Sánchez, F., 2006. Monitoring biomarkers in fish (Lepidorhombus boscii and Callionymus lyra) from the northern Iberian shelf after the Prestige oil spill. Mar. Pollut. Bull. 53, 305-314. https://doi.org/10.1016/j.marpolbul.2006.03.010

Maulvault, A.L., Custódio, A., Anacleto, P., Repolho, T., Pousão, P., Nunes, M.L., Diniz, M., Rosa, R., Marques, A., 2016. Bioaccumulation and elimination of mercury in juvenile seabass (Dicentrarchus labrax) in a warmer environment. Environ. Res. 149, 77-85. https://doi.org/10.1016/j.envres.2016.04.035

McKinney, M.A., Dean, K., Hussey, N.E., Cliff, G., Wintner, S.P., Dudley, S.F.J., Zungu, M.P., Fisk, A.T., 2016. Global versus local causes and health implications of high mercury concentrations in sharks from the east coast of South Africa. Sci. Total Environ. 541, 176-183. https://doi.org/10.1016/j.scitotenv.2015.09.074

Mille, T., Soulier, L., Caill-Milly, N., Cresson, P., Morandeau, G., Monperrus, M., 2020. Differential micropollutants bioaccumulation in European hake and their parasites Anisakis sp. Environ. Pollut. 265, 115021. https://doi.org/10.1016/j.envpol.2020.115021

Monperrus, M., Tessier, E., Veschambre, S., Amouroux, D., Donard, O., 2005. Simultaneous speciation of mercury and butyltin compounds in natural waters and snow by propylation and speciesspecific isotope dilution mass spectrometry analysis. Anal. Bioanal. Chem. 381, 854-862. https://doi.org/10.1007/s00216-004-2973-7

Oksanen, J., Blanchet, F.G., Kindt, R., Legendre, P., Minchin, P.R., O’Hara, R.B., Simpson, G.L., Peter, S., Stevens, M.H.H., Wagner, H., 2013. vegan: Community Ecology Package. R package version 2.0-10.

Pauly, D., Christensen, V., Dalsgaard, J., Froese, R., Torres, F., 1998. Fishing Down Marine Food Webs. Science 279, 860-863. https://doi.org/10.1126/science.279.5352.860

Penglase, S., Hamre, K., Ellingsen, S., 2014. Selenium and mercury have a synergistic negative effect on fish reproduction. Aquat. Toxicol. 149, 16-24. https://doi.org/10.1016/j.aquatox.2014.01.020

Pethybridge, H., Cossa, D., Butler, E.C.V., 2010. Mercury in 16 demersal sharks from southeast Australia: Biotic and abiotic sources of variation and consumer health implications. Mar. Environ. Res. 69, 18-26. https://doi.org/10.1016/j.marenvres.2009.07.006

Pinnegar, J.K., 2014. DAPSTOM - An Integrated Database \& Portal for Fish Stomach Records. Version 4.7. Centre for Environment, Fisheries \& Aquaculture Science, Lowestoft, UK. February 2014, $39 \mathrm{pp}$. 
Pinzone, M., Damseaux, F., Michel, L.N., Das, K., 2019. Stable isotope ratios of carbon, nitrogen and sulphur and mercury concentrations as descriptors of trophic ecology and contamination sources $\begin{array}{llll}\text { of } \quad \text { Mediterranean } & 24448 .\end{array}$ https://doi.org/10.1016/j.chemosphere.2019.124448

Polak-Juszczak, L., 2018. Distribution of organic and inorganic mercury in the tissues and organs of fish from the southern Baltic Sea. Environ. Sci. Pollut. Res. Int. 25, 34181-34189. https://doi.org/10.1007/s11356-018-3336-9

Quéro, J.-C., Vayne, J.-J., 1986. LES POISSONS DE MER DES PÊCHES FRANÇAISES , «Les encyclopédies du naturaliste », ed. Delachaux \& Niestle, 304p.

R Core Team, 2018. R: A language and environment for statistical computing. R Foundation for Statistical Computing, Vienna, Austria. URL https://www.R-project.org/.

Rodríguez Martín-Doimeadios, R.C., Tessier, E., Amouroux, D., Guyoneaud, R., Duran, R., Caumette, P., Donard, O.F.X., 2004. Mercury methylation/demethylation and volatilization pathways in estuarine sediment slurries using species-specific enriched stable isotopes. Mar. Chem., Special Issue in honor of Dr. William F. Fitzgerald 90, 107-123. https://doi.org/10.1016/j.marchem.2004.02.022

Sánchez, F., Gil, J., 2000. Hydrographic mesoscale structures and Poleward Current as a determinant of hake (Merluccius merluccius) recruitment in southern Bay of Biscay. ICES J. Mar. Sci. 57, 152170. https://doi.org/10.1006/jmsc.1999.0566

Savoye, N., David, V., Morisseau, F., Etcheber, H., Abril, G., Billy, I., Charlier, K., Oggian, G., Derriennic, H., Sautour, B., 2012. Origin and composition of particulate organic matter in a macrotidal turbid estuary: The Gironde Estuary, France. Estuar. Coast. Shelf Sci., ECSA 46 Conference Proceedings 108, 16-28. https://doi.org/10.1016/j.ecss.2011.12.005

Sharif, A., Monperrus, M., Tessier, E., Bouchet, S., Pinaly, H., Rodriguez-Gonzalez, P., Maron, P., Amouroux, D., 2014. Fate of mercury species in the coastal plume of the Adour River estuary (Bay of Biscay, SW France). Sci. Total Environ. 496, 701-713. https://doi.org/10.1016/j.scitotenv.2014.06.116

Stefansson, E.S., Heyes, A., Rowe, C.L., 2014. Tracing maternal transfer of methylmercury in the sheepshead minnow (Cyprinodon variegatus) with an enriched mercury stable isotope. Environ. Sci. Technol. 48, 1957-1963. https://doi.org/10.1021/es404325c

Stoichev, T., Amouroux, D., Wasserman, J.C., Point, D., De Diego, A., Bareille, G., Donard, O.F.X., 2004. Dynamics of mercury species in surface sediments of a macrotidal estuarine-coastal system (Adour River, Bay of Biscay). Estuar. Coast. Shelf Sci. 59, 511-521. https://doi.org/10.1016/j.ecss.2003.10.007

Sweeting, C.J., Polunin, N.V.C., Jennings, S., 2006. Effects of chemical lipid extraction and arithmetic lipid correction on stable isotope ratios of fish tissues. Rapid Commun. Mass Spectrom. 20, 595-601. https://doi.org/10.1002/rcm.2347

Timmerman, C.-A., Marchal, P., Denamiel, M., Couvreur, C., Cresson, P., 2020. Seasonal and ontogenetic variation of whiting diet in the Eastern English Channel and the Southern North Sea. PLOS ONE 15, e0239436. https://doi.org/10.1371/journal.pone.0239436

Uriarte, A., Collins, M., Cearreta, A., Bald, J., Evans, G., 2004. Sediment supply, transport and deposition: contemporary and Late Quaternary evolution, in: Borja, A., Collins, M. (Eds.), Oceanography and Marine Environment of the Basque Country. Elsevier, pp. 97-131.

Velasco, F., Olaso, I., 2000. Hake food consumption in the southern Bay of Biscay estimated from a gastric evacuation model. ICES. https://doi.org/ICES CM2000/Q:11.

Villar, E., Cabrol, L., Heimbürger-Boavida, L.-E., 2020. Widespread microbial mercury methylation genes in the global ocean. Environ. Microbiol. Rep. https://doi.org/10.1111/1758-2229.12829

Wang, R., Feng, X.-B., Wang, W.-X., 2013. In Vivo Mercury Methylation and Demethylation in Freshwater Tilapia Quantified by Mercury Stable Isotopes. Environ. Sci. Technol. 47, 79497957. https://doi.org/10.1021/es3043774

Woillez, M., Poulard, J.-C., Rivoirard, J., Petitgas, P., Bez, N., 2007. Indices for capturing spatial patterns and their evolution in time, with application to European hake (Merluccius merluccius) in the Bay of Biscay. ICES J. Mar. Sci. 64, 537-550. https://doi.org/10.1093/icesjms/fsm025 


\section{Electronic supplementary Material}

Table S1: Length and sex effect on $\mathrm{Hg}$ species concentrations according to organs for the three commercial fish species. Results were obtained with a linear regression and illustrated by the $\mathrm{F}$ statistic together with the corresponding p-value (bold for significant value). A log transformation on concentration data proved necessary for the linear regressions in order to achieve the assumption of normality and homogeneity of variance that were checked on residual data.

\begin{tabular}{|c|c|c|c|c|c|c|c|}
\hline & & \multicolumn{2}{|c|}{ Muscle } & \multicolumn{2}{|c|}{ Liver } & \multicolumn{2}{|c|}{ Gonad } \\
\hline & & $\mathrm{MHg}$ & $\mathrm{IHg}$ & $\mathrm{MHg}$ & $\mathrm{IHg}$ & $\mathrm{MHg}$ & $\mathrm{IHg}$ \\
\hline $\begin{array}{l}\text { Hake } \\
\text { Merluccius } \\
\text { merluccius }\end{array}$ & $\begin{array}{l}\text { Length } \\
\text { Sex }\end{array}$ & $\begin{array}{l}\mathbf{F}=\mathbf{5 . 3 5}, \text { p.value }=\mathbf{0 . 0 2 8} \\
F=0.83, \text { p.value }>0.005\end{array}$ & $\begin{array}{l}\mathrm{F}=0.30, \text { p.value }>0.005 \\
\mathrm{~F}=0.30, \text { p.value }>0.005\end{array}$ & $\begin{array}{l}\mathrm{F}=1.77, \text { p.value }>0.005 \\
\mathrm{~F}=0.69, \text { p.value }>0.005\end{array}$ & $\begin{array}{l}\mathrm{F}=0.88, \text { p.value }>0.005 \\
\mathrm{~F}=3.34, \text { p.value }>0.005\end{array}$ & $\begin{array}{l}\mathrm{F}=0.55, \mathrm{p} . \text { value }>0.005 \\
\mathrm{~F}=0.18, \text { p.value }>0.005\end{array}$ & $\begin{array}{l}\mathrm{F}=0.61, \mathrm{p} . \text { value }>0.005 \\
\mathrm{~F}=1.68, \text { p.value }>0.005\end{array}$ \\
\hline $\begin{array}{l}\text { Red mullet } \\
\text { Mullus } \\
\text { surmuletus }\end{array}$ & $\begin{array}{l}\text { Length } \\
\text { Sex }\end{array}$ & $\begin{array}{l}\mathrm{F}=0.23, \text { p.value }>0.005 \\
\mathrm{~F}=2.22, \text { p.value }>0.005\end{array}$ & $\begin{array}{l}\mathrm{F}=0.39, \text { p.value }>0.005 \\
\mathrm{~F}=0.56, \text { p.value }>0.005\end{array}$ & $\begin{array}{l}\mathrm{F}=0.03, \mathrm{p} . \text { value }>0.005 \\
\mathrm{~F}=0.34, \text { p.value }>0.005\end{array}$ & $\begin{array}{l}\mathrm{F}=0.20, \text { p.value }>0.005 \\
\mathrm{~F}=0.69, \text { p.value }>0.005\end{array}$ & $\begin{array}{l}\mathrm{F}=0.12, \mathrm{p} . \text { value }>0.005 \\
\mathrm{~F}=0.01, \text { p.value }>0.005\end{array}$ & $\begin{array}{l}\mathrm{F}=0.72, \text { p.value }>0.005 \\
\mathrm{~F}=5.90, \text { p.value }>0.005\end{array}$ \\
\hline $\begin{array}{l}\text { Sole } \\
\text { Solea solea }\end{array}$ & $\begin{array}{l}\text { Length } \\
\text { Sex }\end{array}$ & $\begin{array}{l}\mathrm{F}=2.70, \text { p.value }>0.005 \\
\mathbf{F}=\mathbf{8 . 9 2}, \text { p.value }=\mathbf{0 . 0 0 5}\end{array}$ & $\begin{array}{l}\mathrm{F}=5.08, \text { p.value }>0.005 \\
\mathbf{F}=\mathbf{5 . 9 3}, \text { p.value }=\mathbf{0 . 0 2 0}\end{array}$ & $\begin{array}{l}\mathrm{F}=0.01, \mathrm{p} . \text { value }>0.005 \\
\mathrm{~F}=2.56, \text { p.value }>0.005\end{array}$ & $\begin{array}{l}\mathrm{F}=0.02, \text { p.value }>0.005 \\
\mathrm{~F}=\mathbf{6 . 6 9}, \text { p.value }=\mathbf{0 . 0 1 4}\end{array}$ & $\begin{array}{l}\mathrm{F}=0.01, \mathrm{p} \cdot \text { value }>0.005 \\
\mathrm{~F}=3.01, \text { p.value }>0.005\end{array}$ & $\begin{array}{l}\mathrm{F}=0.52, \text { p.value }>0.005 \\
\mathrm{~F}=\mathbf{1 7 . 5 5}, \mathbf{p . v a l u e}=\mathbf{0 . 0 0 1}\end{array}$ \\
\hline
\end{tabular}



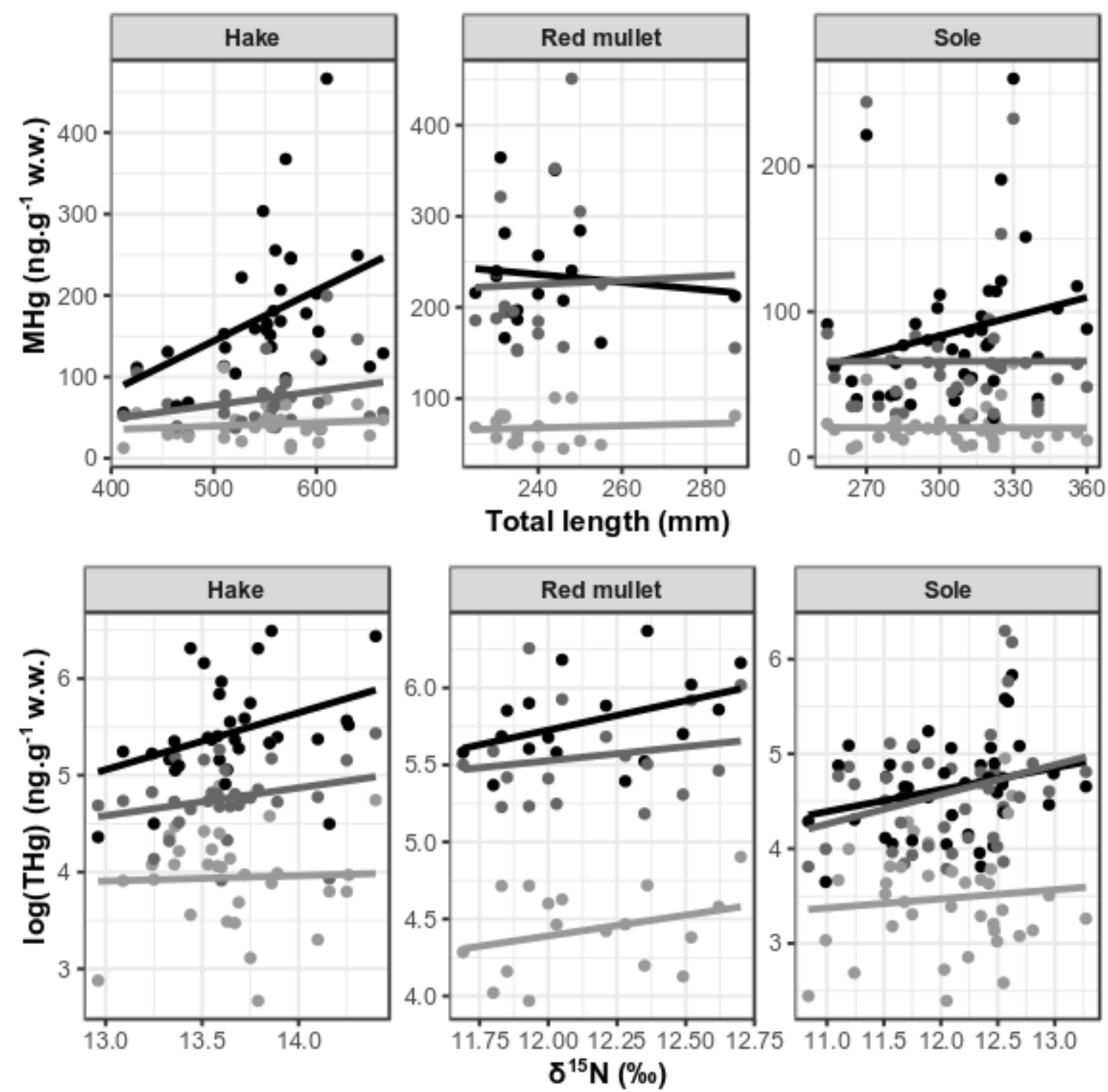
Figure S1: Relationship between MHg and total length (upper row) and relationship between log THg and trophic level (lower row). Colors stand for the organs or tissues considered (muscle in black, liver in medium grey and gonad in light grey) for the three fish species. 


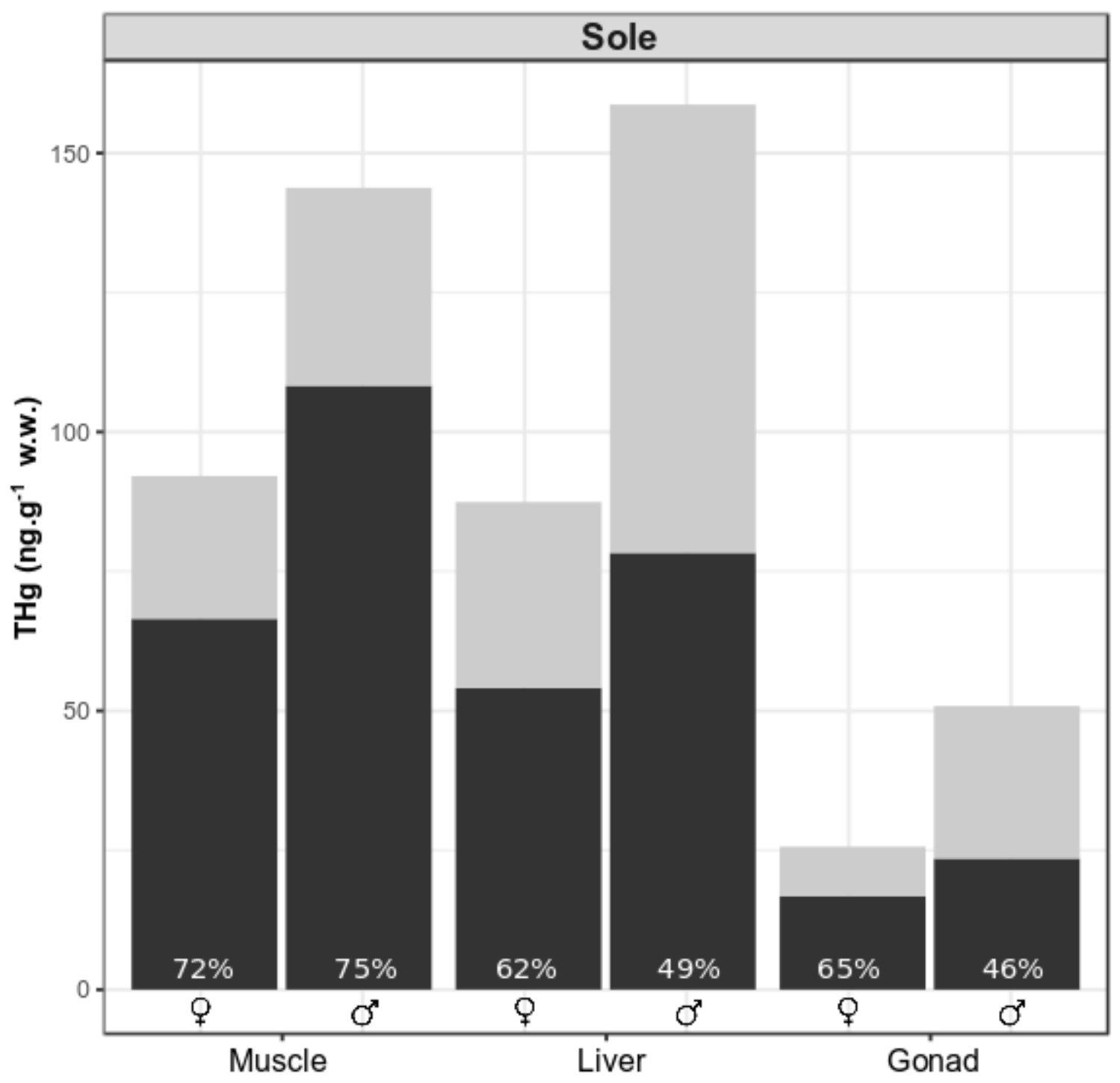

Figure S2: Hg distribution according to organs/tissues and sex for sole Solea solea (MeHg in black together with \% $\mathrm{MeHg}$, and $\mathrm{IHg}$ in grey). Standard deviation are not added for graphical purposes. 